DOI: doi.org/10.21009/IJLECR.052.17

Received: 5 June 2019

Revised: 10 June 2019

Accepted: 14 August 2019

Published: 31 December 2019

\title{
THE EFFECT OF VOCABULARY MASTERY ON THE POETRY WRITING SKILLS
}

\author{
Marlina Bakri ${ }^{1, a)}$ \\ Universitas Cokroaminoto Palopo, Palopo, Indonesia ${ }^{1)}$ \\ lhinam83@gmail.com ${ }^{\mathrm{a})}$
}

\begin{abstract}
This study aims to determine the effect of vocabulary mastery on poetry writing skills. The method used is correlational quantitative research. The population in this study was class X of SMA Negeri 2 Palopo, while the sample was 176 students. Data collection was conducted using a test instrument, and then the data obtained in this study were analyzed using SPSS V.20 . Based on the results of descriptive statistical calculations with the help of SPSS, it was found that the vocabulary mastery variable had an average value of 68.77, a standard deviation value of 5.416, a median value of 69, and a mode value of 67 . From the 176 students, the lowest value was 52 as many as 1 person, with a percentage of $0.6 \%$, while the highest value is 84 as many as 1 person with a percentage of $0.60 \%$. Based on the results of these calculations, the level of mastery of student vocabulary is high, which is $81.86 \%$. Furthermore, the results of data analysis and statistical calculations found the results of this study, namely, there is a correlation between mastery of vocabulary $(\mathrm{X})$ on poetry writing skills (Y) which is $19.9 \%$. How to conduct and determine the assessment on the poetry writing is also discussed.
\end{abstract}

Keywords: vocabulary mastery, poetry writing, writing skills.

Writing is an inseparable part of the Indonesian language given with the aim that students can express their thoughts, ideas, thoughts and feelings in written language in an orderly and smooth manner. The emergence of planned writing learning is very helpful because the skills to write some of the skills are supported. Writing means organizing ideas systematically, and expressing them explicitly. Writing skills do not come automatically, but must go through training regularly. Writing is an important medium for expressing yourself personally, and finding meaning. Therefore, practice and writing practice remain an important part and are a central part of language teaching.

The skills of writing learning carried out in schools have various forms, one of which is poetry writing skills. Learning to write poetry in students is not only limited to looking at diction or choice of words, but students must be able to master the vocabulary well. The importance of writing poetry, because it is a language skill needed to improve the quality of literary learning.

Based on the results of interviews with one of the schools in Palopo, problems were found in writing poetry, such as, there was no interest, lack of ideas, and the vocabulary was still very minimal, so that students had difficulty completing the poem in full. Basically poetry writing skills have been taught, but the results achieved have not been maximized. Problem solving to optimize the achievement of the purpose of writing poetry through a process approach. The role of a teacher 
greatly determines the success of student writing learning. So far, the teacher still uses the method of focusing on questions and answers and assignments. Most teachers only teach poetry theory and how to write poetry, without trying to guide and direct in writing a poem. Some studies on writing poetry and vocabulary studies, including research conducted by Ozen \& Mohammadzadeh[1]Khatib\& McIhami[2] who concluded that the acquisition of vocabulary, mechanics, collaborative techniques can support one's success in learning to write poetry.

Vocabulary is the wealth of language that someone has that can be used to communicate, both verbally and in writing. Mastery of vocabulary according to the situation will foster an attitude in choosing the right words. This means that knowledge, understanding, and application are reflected in one's language skills depending on the quality and quantity of vocabulary possessed. The easier a person understands other people's thoughts, the more vocabulary they have and the more skilled they are in writing poetry. The purpose of this study is to determine the effect of vocabulary acquisition on poetry writing skills.

\subsection{Vocabulary}

Vocabulary refers to a lexical set including single words, compound words, and idioms (Richards \& Schmidt in Pourdana [3]). Thus, vocabulary learning is defined as the process of obtaining words of pronunciation and complex meanings. Vocabulary is a wealth of languages (words) in someone who has a certain meaning and in it there are single words, complex words, and idioms. Vocabulary learning is an important process for success in language acquisition, which involves not only students, knowledge of word definitions, but also their attention to different aspects of words, such as synonyms and pronunciation[4].

Tarigan[5]suggests that mastery of vocabulary is the ability to clarify and choose (master) vocabulary, both in the presentation of sentences derived from the basic words or derived through affixes both prefixes and endings. Mastery of vocabulary includes mastery of terms, mastery of expressions, synonyms of words, abstract-concrete words, general-specific words, and includes the word assignments and acronyms. As stated by Al-Shabab[6]that in essence poetic vocabulary aims to express the concept of the environment, experience and identity of the poet. Lexical choices define the fundamental layer in which all concepts, including terminology, propositions, feelings and references. Uhlenbeck [7] argues that: 1) each language has a collection of words; 2) it is possible to determine the vocabulary of each language; 3 ) therefore each language is a system that is a group of elements arranged functionally, then all words are included in the linguistic system; 4) a system that collects phonematic word forms consisting of various systems in each language there is one main part system; and 5) to investigate the morpheme system an inventory must be carried out. It was concluded that vocabulary mastery is the ability of individuals to master a number of vocabulary or vocabulary in a language to be mastered by someone who can be used appropriately, both passive-receptive and actively productive mastery.

\subsection{Assessment of vocabulary mastery}

One method that can be used in implementing vocabulary tests as part of language teaching is the use of teaching material as a source of testing. By continuing to distinguish between receptive and active productive passive skills in language learning, including vocabulary mastery, vocabulary test forms that can be used: showing objects, demonstrating, giving equivalents, giving other words, giving opponents words, mentioning words, and completing sentences[8].

\subsection{Poetry writing skills}

The writing skills are complex and difficult to teach, requiring mastery not only of devices but also of conceptual and judgement elements [9]. Writing skills that are complex and difficult to teach, require mastery of grammar tools and also require other conceptual and valuation elements. Writing skills that are conveying messages to others in writing. The skills in question are not only related to 
the students' skill in composing and writing written symbols, but also expressing their thoughts, opinions, attitudes and feelings clearly and systematically so that they can be understood by those who receive them.

In one sence, poetry Writing requires a lot of pat.ence-perhaps more so than writing fiction or non - fiction - as more time is spent concentratingon the smaller details. With a poem you are focusing upon individual word and phrases stanzas, or even the combinatory the onthering of the lines and the stanzazs, or even the combination of ord sounds or the number of beats ina farticula line. On the one hand writing requires a lot of patience maybe more than writing fiction or nonfiction, because more time is spent concentrating on smaller details, with your poetry focusing on words and phrases or ordering from lines and stanzas, or even combinations word or number of beats in a certain line [10].

The term poetry comes from the Greek poesis, which means that creation and in English is called poetry, is one genre of literature that has the characteristics of the form of writing that is binding and different from the way of expressing other types of literature. Poetry is a form of literature that uses beautiful words and is rich in meaning. The beauty of a poem is caused by diction, majas, rima, rhythm contained in the literary work[11]. Poetry uses concise language but its meaning is very rich. The word used is a connotative word that contains a lot of interpretation and understanding.

Emzir and Saifur Rohman [12]suggest that poetry is an indirect expression, namely expressing something with another meaning. Indirect expression is caused by: a) displacing of meaning; $b$ ) distorting of meaning; and c) creating of meaning. The meaning of the meaning of poetry as a whole according to normative grammar is in accordance with the first level system. It gives meaning to poetry or literary meaning. It was concluded that poetry is a literary work created from a mind, feeling in beautiful language or beauty is the nature and characteristics, places, objects or ideas that provide experiences of perceptions of pleasure and connection between words, thus giving a solid and imaginative meaning through beautiful language and full of figures.

\subsection{Assessment of poetry writing}

Writing skills can be assessed using several assessment techniques (scoring) that have been developed by experts. Each type of scoring rubric has advantages and disadvantages, so taking into account the advantages and disadvantages can determine the type of instrument that is suitable for use. Heaton [9]suggested three ways of assessing writing skills, namely: 1) method of calculating errors; 2) analytical methods; and 3) multiple impression or valuation methods. The error counting method is applied by adding all errors in the writing. This method has its disadvantages of ignoring content and being dishonest because certain types of errors are sometimes more serious than others. Analytical methods assess writing based on the quality of its components (fluency, grammar, vocabulary, content, and mechanics).

Brown[13]proposed three main types of approaches used in the assessment of writing skills, namely: holistic, primary trait, and analytic. Brown's holistic method tends to give one single value after the overall results of the student's writing (test takers). This holistic technique has advantages, namely: 1) rapid assessment; 2) relatively high inter-rater reliability; 3 ) can be applied to assess writings from various scientific disciplines. The disadvantages of this technique include: 1) not providing diagnostic information; 2) one single score represents all the components needed in writing; and 3) rather complicated in application because the assessors are trained extensively to use rating scales accurately. The primary trait assessment technique focuses more on assessing students' abilities. This type of assessment gives a score based on the effectiveness of achieving the text at one goal. In order to measure students' skills in writing poetry, it is necessary to test students. Considering writing poetry is an activity that ultimately produces a form of work in the form of poetry, the test used is an essay writing poetry test. 
Argues that the study of a number of texts (complete: literary texts), which are thought to have certain relationship forms, for example to find a connection between intrinsic elements such as ideas, ideas, events, plots, characterizations, (styles) languages, and others, among the texts studied(Teeuw in Nurgiyantoro[14]).More specifically, it can be said that the intertext study seeks to find certain aspects that have existed in previous works in the work that appears later. essay tests are tests of thought processes that involve high level cognitive activity, demanding students' ability to apply knowledge, analyze, connect concepts, assess and solve problems.

\section{METHODS}

This study uses a correlational quantitative research method with path analysis techniques. Correlational research is sometimes descriptive research, because it describes a condition that already exists. Path analysis is used to determine a number of pathways that connect one variable to another [15]. This study, the authors analyzed the relationship of variable $\mathrm{X}$ to $\mathrm{Y}$, namely the influence of vocabulary mastery on poetry writing skills. The correlational design uses statistical correlation to describe and measure the degree or relationship of relations between variables or series of scores. The procedure used by correlational researchers is collecting quantitative data, questionnaires or interviews and analyzing statistical data to explain the issues that occur and to test research questions or hypotheses.

\subsection{Population and sampels}

The population in this study were all students who attended education at SMA Negeri 2 Palopo in the 2017/2018 school year. While the affordable population is all students who are studying in class X 2017/2018. In quantitative research, the sample is a very crucial issue that can determine the validity of the results of the study. By using the formula for determining the number of samples, namely:

$n=\frac{N}{1+N \cdot e^{2}}$

$\mathrm{n}=$ Number of sample members

$\mathrm{N}=$ number of population members

$\mathrm{e}=$ error tolerance limit (level of tolerance) which is 0.05 .

Based on this formula the sample selected in this study was 176 students. The sampling technique used in this study was a random sampling technique.

\subsection{Research instrument}

Based on this formula the sample selected in this study was 176 students. The sampling technique used in this study was a random sampling technique.

\subsection{Data collection and analysis techinique}

The data in this study were collected by means of tests. Questionnaire is used to collect vocabulary mastery data (X) and tests are used to collect data on writing poetry skills (instrument $\mathrm{Y}$ ). Furthermore, data analysis uses inferential analysis. Inferential analysis is used to test hypotheses using path analysis. Before the data is analyzed by path analysis, the analysis requirements are carried out first, namely by conducting a normality test and linearity test of the data. To determine the path coefficient requirements are needed such as: path analysis to recognize two types of variables, namely exogenous variables and endogenous variables. Exogenous variables are direct or indirect influences on endogenous variables. Endogenous variables are variables that can affect variaebel endogenous.

Path analysis is a development technique from multiple linear regression. This technique is used to test the size of the contribution (contribution) indicated by the path coefficient on the path diagram of the causal relationship between variables X to Y. Data will be processed with SPSS which will display several tables with summaries of calculation results and path coefficient testing. 
Overall test or F test, then continued by individual test or $\mathrm{t}$ test. The hypothesis of this study is that there is a direct effect of mastery of vocabulary $(\mathrm{X})$ on poetry writing skills (Y).

To test this hypothesis using the $\mathrm{F}$ test with the criteria: Ho is accepted, if $\mathrm{Fh}<\mathrm{F}$ table, and Ho is rejected, if $\mathrm{Fh}>\mathrm{F}$ table.

The price of Fh is determined by the formula:

$\mathrm{Fh}=\frac{\mathrm{R} 2 \mathrm{y} \cdot 123(\mathrm{n}-\mathrm{k}-1) \mathrm{k}(1-\mathrm{R} 2 \mathrm{y} \cdot 123)}{}$

$\mathrm{k}=$ number of independent variables

$\mathrm{n}=$ number of pairs of data (number of sample subjects)

Ftable $=$ is determined from the distribution table $\mathrm{F}$ for certain $(\propto=0.05)$ and $\mathrm{dk}_{\text {numerator }}=\mathrm{K}$ and $\mathrm{dk}_{\text {denominator }}=\mathrm{n}-\mathrm{k}$

\section{RESULTS AND DISCUSSION}

The variables in this study are grouped into two, namely exogenous variables (independent variables) and endogenous variables (dependent variables). Exogenous variables, namely vocabulary mastery $(\mathrm{X})$ and endogenous variables are poetry writing skills $(\mathrm{Y})$.

\subsection{Vocabulary mastery}

Data obtained in the field are then processed statistically into the frequency distribution list. Based on the results of descriptive statistical calculations with the help of SPSS, it was obtained that the vocabulary mastery variable had an average value of 68.77 with a standard deviation of 5.416; median value 69; and a mode value of 67.

Furthermore, the percentage level of mastery of the vocabulary 176 samples can be calculated through a comparison of the average score of the sample per maximum score.

The percentage level of mastery of vocabulary can be calculated as below.

$=\frac{\text { Average Score of Respondents }}{\text { Maxsimum Score of Respondents }} \times 100 \%$

$=\frac{68.77}{84} \times 100 \%=81.86 \%$

Based on the results of these calculations, the level of mastery of student vocabulary is high, which is $81.86 \%$.

\subsection{Poetry writing skills $(Y)$}

The results of descriptive statistical calculations with the help of SPSS obtained that the variable poetry writing skills have an average value of 83.16 with a standard deviation value of 6.073 ; median value 83; and a mode value of 81 .

Furthermore, the percentage of 176 sample poetry writing skills can be calculated through a comparison of the average sample score per maximum score.

The percentage of poetry writing skills can be calculated as below.

$=\frac{\text { Average Score of Respondents }}{\text { Maxsimum Score of Respondents }} \times 100 \%$

$=\frac{83.16}{98} \times 100 \%=84.85 \%$

Based on the results of these calculations, the level of students' poetry writing skills is high, amounting to $84.85 \%$.

\subsection{Testing Requirements Analysis}

The use of parametric statistics works with the assumption that the data for each research variable to be analyzed forms a normal distribution. The process of testing the requirements of analysis in this study is a requirement that must be fulfilled so that the use of regression techniques that are included in the group of parametric statistics can be applied for the purposes of hypothesis testing. 
Terms of path analysis are estimates of exogenous variables on endogenous variables that are linear, thus the requirements that apply to regression analysis automatically apply to the requirements of path analysis. The requirements that must be met in path analysis are that the research sample comes from a population that is normally distributed and the relationship between the variables in the model must be significant and linear. Thus, before testing the model, a test of the two requirements in the path analysis is carried out first. The test of the analysis performed is the normality test, linearity test, and significance of the regression coefficient.

The calculation and analysis of each normality test and linearity test and the significance of the regression coefficients are described as follows.

1.10.1. Normality test. The results of the testing of the research instrument are used to draw the conclusion that the population observed is normally distributed or not. For the KolmogorovSmirnov $\mathrm{Z}$ test. In this test first the error (sample) is arranged according to the order of values, then the default number $(\mathrm{Zi})$, the frequency $\mathrm{S}(\mathrm{Zi})$, and the lowest frequency $\mathrm{F}(\mathrm{Zi})$ then the lowest frequency difference is determined and the real frequency for each error value. The absolute maximum price of the difference is referred to as $t_{\text {count }}$. The value of $t$ count is then compared with $t_{\text {table }}$ for the real level $\alpha=0.05$. Proposed hypothesis as follows:

Ho: Data is normally distributed, if the value of $t_{\text {count }} \leq$ the value of $t_{\text {table. }}$.

Data Normality: Hi: Data is not normally distributed, if the value is $t_{\text {count }}>t_{\text {table }}$.

From the calculation of the normality test of poetry writing skills $(\mathrm{Y})$ on vocabulary mastery (X) obtained Kolmogorov-Smirnov $\mathrm{Z}$ value $=0.929$, where the significance value is equal to 0.353 this value is greater than $\alpha=0.05$. then the regression estimate $Y$ over X is declared normal.

1.10.2. Linearity Test and Significance of Poetry Writing Skills Regression Coefficient $(Y)$ on Vocabulary Mastery (X). The calculation data for the preparation of the regression equation model between poetry writing skills and vocabulary mastery obtained a regression constant $\mathrm{a}=12,559$ and a regression coefficient $b=1,027$. Thus the relationship of a simple linear regression equation model is $\hat{Y}_{\mathrm{y}}=12,559+1,027 \mathrm{X}$. Before the regression equation model is further analyzed and used to draw conclusions, first test the significance and linearity of the regression equation. The results of the calculation of significance and linearity tests are arranged in the ANAVA table as in the following table.

Table 1. ANOVA for linearity test and significance of the regression coefficient in the equation $\hat{Y}_{\mathrm{y}}=12,559+1,027 \mathrm{X}$

\begin{tabular}{|l|l|l|l|l|l|l|l|}
\hline \multicolumn{2}{|c|}{} & $\begin{array}{c}\text { Sum of } \\
\text { Squares }\end{array}$ & Df & $\begin{array}{c}\text { Mean } \\
\text { Square }\end{array}$ & F & Sig. \\
\hline $\begin{array}{l}\text { Y* } \\
\text { X1 }\end{array}$ & $\begin{array}{l}\text { Between } \\
\text { Groups }\end{array}$ & (Combined) & 5640.146 & 29 & 194.488 & $\begin{array}{l}34.82 \\
4\end{array}$ & .000 \\
\cline { 3 - 8 } & Linearity & 5411.444 & 1 & $\begin{array}{l}5411.44 \\
4\end{array}$ & $\begin{array}{l}968.9 \\
37\end{array}$ & .000 \\
\cline { 3 - 8 } & $\begin{array}{l}\text { Deviation from } \\
\text { Linearity }\end{array}$ & 228.701 & 28 & 8.168 & 1.462 & .078 \\
\cline { 3 - 9 } & & 815.400 & 146 & 5.585 & & \\
\hline
\end{tabular}

Based on the table, on the line Deviation from Linearity the value of $F=1.462$ with a significance value of 0.078 is greater than the value of $\alpha=0.05$, then the distribution of estimated points forming linear lines can be accepted. 


\subsection{Model testing}

1.11.1. Correlation coefficient calculation.From the results of the analysis and the calculation process carried out, the results of the calculation of the correlation between vocabulary mastery (X) and poetry writing skills (Y) amounted to 0.916 . That is, there is a relationship between vocabulary mastery and poetry writing skills.

1.11.2. Matrix of inter-variable structural relations model. Calculate the value of $t_{\text {count }}$ on the path coefficient to determine the significance of the effect given by each independent variable on the dependent variable. A summary of the structural relations model between variables can be presented in the path diagram as follows:

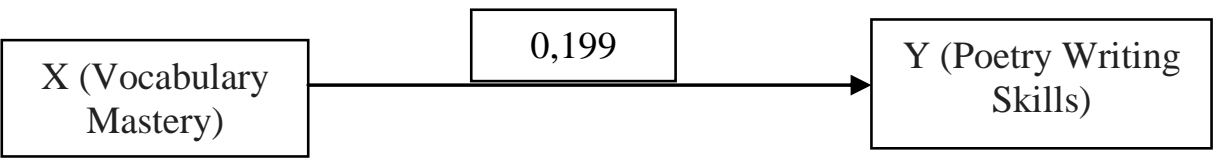

Figure of the structural relationship model between variables

1.11.3. between variables. The results of the correlation coefficient use the SPSS results as in the following table. Calculation of structural model path coefficients. Calculation of structural model path coefficients is based on the value of the correlation coefficient.

Table 2. Summary of path coefficient value

\begin{tabular}{|l|l|l|l|l|l|}
\hline Path & Path coefficient & \multirow{2}{*}{$\mathbf{T}_{\text {count }}$} & \multicolumn{2}{|c|}{$\mathbf{t}_{\text {table }}$} & \multirow{2}{*}{ Coefficient } \\
\cline { 4 - 5 } & & & 0,05 & 0,01 & \\
\hline $\mathbf{1}$ & py1 & 5,112 & 1,654 & 2,348 & Very significant \\
\hline
\end{tabular}

The table above shows that paths have very significant coefficients, namely path pyl has a significant coefficient. Thus, because the path shows a coefficient, a modified structural model is not needed. So, the existing structural model is appropriate. The path coefficient appears that $\mathrm{pY} 1=$ $0.199 ; \mathrm{t}_{0}=5.112$, p-value $0.000 / 2=0,000<0.05$, or $\mathrm{H}_{0}$ is rejected, which means there is an influence of vocabulary mastery $(\mathrm{X})$ on poetry writing skills $(\mathrm{Y})$.

\subsection{Hypothesis testing}

The results obtained after conducting a model analysis are used as a basis in answering hypotheses and drawing conclusions in this study. An explanation of the answers to these hypotheses can be described as below.

Mastery of vocabulary (X) has a direct positive effect on poetry writing skills (Y).

$\mathrm{H}_{\mathrm{O}}: \beta \mathrm{y} 1 \leq 0$

$\mathrm{H}_{\mathrm{i}}: \beta \mathrm{y} 1>0$

$\mathrm{H}_{\mathrm{O}}$ rejected, if $\mathrm{t}_{\text {count }}>\mathrm{t}_{\text {tabel }}$

The results of the calculation of path analysis, a direct positive effect of mastery of vocabulary $(\mathrm{X})$ on poetry writing skills $(\mathrm{Y})$, path coefficient value of 0.199 ; $\mathrm{t} 0=5.112$, p-value $0.000 / 2=$ $0,000<0.05$, or $\mathrm{H}_{0}$ is rejected, which means that there is an influence of mastery of vocabulary (X) on poetry writing skills (Y).

The results of the first hypothesis analysis provide findings that vocabulary mastery has a direct positive effect on poetry writing skills. Thus, it can be concluded that poetry writing skills are positively influenced directly by the vocabulary mastery. Increased mastery of vocabulary will 
affect the increase in poetry writing skills by $19.9 \%$.

From the analysis of these two variables by looking at the relationship between the two, it can be said that the higher the level of students' vocabulary mastery, the better their poetry writing skills. In other words, acquiring and mastering one's vocabulary is decisive in improving the students' poetry writing skills. Therefore, the application of diverse and collaborative techniques by teachers is highly recommended in the vocabulary learning process with the aim of mediating the acquisition of student vocabulary as well as in terms of their use. This is in line with research conducted by Ozen\&Mohammadzadeh[1] and Khatib\& Meihami[2] that collaborative techniques in vocabulary acquisition can support the students' learning in relation to poetry writing skills.

If it is payed attention, the improvement of the students' poetry writing skills is not only identified by the vocabulary mastery factor but also how students understand and focus carefully on words[10], both in its conceptual elements and in their assessment[9], and all forms of different aspects of the words they use when writing poetry[4]. Writing poetry does not only require the words that have been acquired but the students' ability to abstract the words into beautiful or meaningful phrases or sentences would be the important one. However, beautiful words are not only a determining factor in composing a poem but the essence of poetic words must be able to express the environmental concepts referred to in the poem, the experiences of the author, and the identity of the poem alone[6].

The increase in the students' vocabulary mastery and writing skills is certainly based on an assessment. However, an assessment certainly has an influence in determining the success and failure of students in achieving mastery and skills in question. The results of this study are also the generation of a test measured by statistical use. In connection with this matter, Brown [13] has given a clear picture of how to judge a poem by evaluating it holistically, considering the main nature of the assessment itself on the work of students, and the assessment is analytic. This is done by considering that writing poetry does not only use words but more than that, a poem writing considers the time spent by students in concentrating on determining the most detailed of the words and phrases used to arrange lines and stanzas and the number of stanzas in a certain line[10] and consider the beauty of poetry that is formed from dictionaries, majas, rhymes, rhythm[11]. Therefore, the evaluation of a poem is not an easy job because in addition to determining the value of a poem, also because poetry is an indirect expression, it is expressing something with another meaning[12].

\section{CONCLUSION}

Based on the results of the study, it can be concluded that vocabulary mastery has a direct positive effect on students' poetry writing skills, with the path coefficient value of 0.856 and the amount of direct influence 0.199 . Thus, mastery of vocabulary significantly influences the quality of students' poetry writing skills. The higher the students' vocabulary mastery, the better the quality of poetry writing skills. Further, relating to the vocabullary learning, the teacher should have the various strategy in the teaching of vocabullary in order to have the students acquire all different elements of words the students use in writing the poetry as well as the consideration in conducting and determining the ideal assessment.

\section{REFERENCES}

Ozen, B. \& B. Mohammadzadeh, “Teaching Vocabulary through Poetry in an EFL Classroom,” Int. Online J. Prim. Educ., vol. 1, no. 1, pp. 58-72, 2012.

Mohammad, K. \& H. Meihami, "Languaging and Writing Skill : The Effect of Collaborative Writing on EFL Students' Writing Performance," Adv. Lang. Lit. Stud., vol. 6, no. 1, 2015. Pourdana, N. "Metaphorical Awareness : A New Horizon in Vocabulary Retention by Asian EFL 
Learners,” Int. J. Appl. Linguist. English Lit., vol. 3, no. 4, pp. 213-220, 2014.

Al-Mahbashi, A.A.,\&Noorizah Mohd Noor, Z. Amir, "The Effect of Multiple Intelligences on DDL Vocabulary Learning,” Int. J. Appl. Linguist. English Lit., vol. 6, no. 2, 2017.

Tarigan, H. G. Pengajaran Kosakata[Vocabulary Teaching]. Bandung: Angkasa, 2015.

Al-shabab,O.A.S. "Construction and Interpretation Of Corpus-Based English Poetry Vocabulary Profile,” Int. J. Appl. Linguist. English Lit., vol. 6, no. 5, 2017.

Uhlenbeck, E.M. Kajian Morfologi Bahasa Jawa[Morphological Study of Javanese Language]. Jakarta: Djambatan, 1982.

Djiwandono, S. Tes Bahasa: Pegangan bagi Pengajar Bahasa[Language Test: A Handbook for Language Teachers]. Jakarta: Indeks, 2011.

Heaton, J. B. Longman Handbooks for Language Teachers. New York: Longman Inc, 1990.

Carter, J. Creating Writers A Crative writing manual for schools. New York: RoutledgeFalmer, 2001.

Kosasih, E. Dasar-dasar Keterampilan Menulis[Basics of Writing Skills]. Bandung: Yrama Widya, 2014.

Emzir \& S. Rohman.Teori dan Pengajaran Sastra[Theory and Literature Teaching]. Jakarta: Rajawali, 2015.

Brown, H. D. Language Assessment Priciples and Classroom Practices. New York: Pearson, 2010.

Nurgiyantoro, B. Penilaian Pembelajaran Bahasa Berbasis Kompetensi, $2^{\text {nd }}$ ed. [Competency Based Language Learning Assessment, $2^{\text {nd }}$ ed.] Yogyakarta: BPFE, 2016.

Emzir.Metodologi Penelitian Pendidikan Kuantitatif \& Kualitatif[Quantitative \& Qualitative Education Research Methodology]. Jakarta: Raja Grafindo Persada, 2015. 